\title{
STAKEHOLDER PERCEPTIONS OF DECISION-MAKING PROCESS ON MARINE BIODIVERSITY CONSERVATION ON SAL ISLAND (CAPE VERDE)*
}

\author{
Jorge Ramos ${ }^{I}$, Miguel Tiago Oliveira ${ }^{2}$ and Miguel N. Santos ${ }^{1 * *}$ \\ ${ }^{1}$ INRB I.P./L-IPIMAR \\ (Avenida 5 de Outubro s/n 8700-305 Olhão, Portugal) \\ ${ }^{2}$ Oceanário de Lisboa S.A. \\ (Esplanada D. Carlos I, 1990-005 Lisboa, Portugal) \\ ***Corresponding author: mnsantos@ipimar.pt
}

\begin{abstract}
A B S T R A C T
In the Sal Island (Cape Verde) there is a growing involvement, will and investment in the creation of tourism synergies. However, much of the economic potential of the island can be found submerged in the sea: it is its intrinsic 'biodiversity'. Due to this fact, and in order to balance environmental safety and human pressure, it has been developed a strategy addressing both diving and fishing purposes. That strategy includes the deployment of several artificial reefs (ARs) around the island. In order to allocate demand for diving and fishing purposes, we have developed a socio-economic research approach addressing the theme of biodiversity and reefs (both natural and artificial) and collected expectations from AR users by means of an inquiry method. It is hypothesized a project where some management measures are proposed aiming marine biodiversity conservation. Using the methodology named as analytic hierarchy process (AHP) it was scrutinized stakeholders' perception on the best practice for marine biodiversity conservation in the Sal Island. The results showed that to submerge obsolete structures in rocky or mixed areas have a high potential, but does not gathers consensuality. As an overall conclusion, it seems that limitation of activities is the preferred management option to consider in the future.
\end{abstract}

\section{RESUMO}

Na Ilha do Sal (Cabo Verde) existe um crescente envolvimento, vontade e investimento na criação de sinergias turísticas. Contudo, muito do potencial económico da ilha está submerso - a biodiversidade marinha. Devido a este facto, e tendo em vista promover a sustentabilidade ambiental associada ao eco-turismo, vem sendo desenvolvida uma estratégia direccionada, quer ao mergulho, quer à pesca. Esta estratégia inclui a implantação de vários recifes artificiais (RA) na Baía de Santa Maria. De modo a alocar a procura para propósitos como o mergulho e a pesca, desenvolvemos um plano de pesquisa socio-económica relativo ao tema da biodiversidade e recifes (naturais e artificiais) e recolhemos as expectativas dos utilizadores de RAs. Assim, foi elaborado um projecto teórico cujo objectivo é a conservação da biodiversidade marinha, no qual são propostas algumas medidas de gestão. Através da utilização do método designado por processo analítico hierárquico (PAH) foi escrutinada a percepção dos utilizadores sobre as melhores práticas para a conservação da biodiversidade marinha na Ilha do Sal. Os resultados mostraram que o afundamento de estruturas obsoletas em áreas rochosas ou mistas parece ter um grande potencial, mas não é consensual. Em conclusão, a limitação de actividades de mergulho afigura-se como uma opção a considerar futuramente.

Descriptors: Marine biodiversity conservation, artificial reef project, Sal Island (Cape Verde), underwater tourism, Analytic hierarchy process (AHP).

Descritores: Conservação da biodiversidade marinha, Projeto de recifes artificiais, Ilha do Sal (Cabo Verde), Eco-turismo subaquático, Processo analítico hierárquico (PAH). 


\section{INTRODUCTION}

Many island microstates develop tourism activities as an alternative form of economic development, assuming that international tourism continues to grow (WILKINSON, 1989). One type of tourism that has grown dramatically in recent years is related to wildlife and biodiversity watching. Many tourism companies operate in this segment and promote products with a view to satisfying their clientele. This activity, also related to ecotourism, is based on management procedures intended to supply conservation services whereby the natural and cultural heritage should be preserved. According to Tapper (2006), these services usually involve local communities both in their planning and operation, and contribute to their wellbeing through the creation of jobs (e.g., as guides to visitors). Ecotourism enterprises imply strong, lasting and equitable partnerships with local communities and also protect the environment. In this field of activity there are several examples of highly successful projects (PARKER; KHARE, 2005).

BOURDET (2000) observes that Cape Verde has several structural development constraints (e.g., poor location and inadequately developed physical infrastructure). This small country has some agricultural products (e.g., bananas, sugarcane and coffee, among others) and some natural resources (e.g., fish and salt). There are also some industries producing fish and fish products and ship-building and repairing. But the main economic potential of the country is to be found in the sea. Cape Verde has a low per capita Gross Domestic Product (GDP) (MCELROY; MORRIS, 2002), but in 2003 the UN Economic and Social Council recommended that Cape Verde should be upgraded from the list of Least Developed Countries (LDC), mainly due to increases in its per capita GDP. The country is preparing a National Strategic Development Plan for Tourism and is establishing a national school for hotel and tourism activities (LOPER et al., 2005). This means that the tourism sector is becoming the most important in Cape Verde and is the most promising (ALVES et al., 2000) (CHRISTIE; CROMPTON, 2001). For instance, Sal Island is becoming very popular for underwater tourism and is able to take advantage of the international airport located on the island (IRWIN; WILSON, 2009).

In the Cape Verde archipelago, the island shelf, of limited extent, is associated with a relatively low primary production and consequently the biodiversity is apparently lower than that of the African continental coast (MENEZES et al., 2004). The ichtyofauna is of tropical type. As Cape Verde is an archipelago there are a few dozen endemic taxa, probably due to speciation related to isolation and thermal stability (BRITO et al., 2007). In Cape Verde in recent years there has been a perceptible decline in the biodiversity of local marine life, especially due to increasingly intensive and unregulated fishing practices. As a result, underwater tourism may be affected by virtue of there being 'less to see'. However, increasing diving tourism may also jeopardize marine biodiversity if it continues to grow uncontrolled. Due to these threats and well aware of the need to contribute positively to providing quick answers to the issues mentioned, a local diving operator, with the agreement of Cape Verde's Ministry of the Environment, took the first step in this direction when it launched the Rebuilding Nature Project Artificial Reefs in Cape Verde (www.rebuildingnature.org).

The first record of benefits arising from artificial reefs comes from Japan, where in the Kansei Era (1789-1801) a fisherman caught an immense quantity of large sea-bream near a ship wreck. When the wreck vanished the fish stopped shoaling there. Thus did the relationship between sunken structures and increased catch come to light. The construction of devices to attract shoals and increase the wealth of fishermen and their families then spread to fishing communities throughout Japan (MOTTET, 1985). By virtue of this empirical knowledge and further experience, there emerged the idea that by placing suitable long-lived, stable and environmentally safe materials (usually steel or concrete) in an area of the sea bottom selected a priori, marine life would be attracted and biodiversity of all kinds promoted. It has been demonstrated that ARs have a relatively higher potential than does empty space (GROVE; SONU, 1985). Seaman Jr. and Jensen (2000) observe that any AR exercises an influence not only on the biological context, but also on the physical and socio-economic processes related to living marine resources. In many places worldwide, ARs have been deployed for the purpose of stimulating commercial or recreational fishing activity, or simply as a protection for fish and the marine habitat (MILON, 1989a, b). It is now generally accepted that AR purposes may vary or be combined. Various social and economic methods have been proposed for the appraisal of ARs (MILON et al., 2000). For instance, within that purpose it is possible to find studies on the demand for vessels-reefs generated by diving activities, which is one example of economic opportunity created by underwater tourism (LEEWORTHY et al., 2006; MORGAN et al., 2009).

Biodiversity management presupposes both the desire to enhance the tourist experience and also to protect the local fauna and flora. For this it is necessary to discover how tourists see proposed biodiversity management arrangements. The scrutiny of tourist preferences for biodiversity management is 
thus essential (SEMENIUK et al., 2009). However, this decision-making question may pose some difficulty in terms of accurately quantifying people's preferences as regards management alternatives.

In order to adjudge demand for sustained diving and fishing purposes, we have developed a socio-economic research strategy for Sal Island. It is presupposed that there is funding available to support an environmental project, in terms of social responsibility, aiming at marine biodiversity conservation. In accordance with that purpose, four management measures, related to the motivation for reef diving, are proposed. However, due to the limitation of financial resources, it is necessary to choose the best practice in terms of the allocation of money. By using the analytic hierarchy process (AHP), stakeholders' perceptions as to the best practice for marine biodiversity conservation were investigated.

\section{Study Area}

Cape Verde is an archipelago of ten main islands and some islets located in the North Atlantic off West Africa. Sal Island is one of the most easterly islands of the windward group. It is relatively flat and arid, with sparse vegetation. However, its flat terrain led to its choice as the site for the country's main international airport in 1939. The island was almost uninhabited, but that development triggered some immigration from the neighboring islands (mainly S. Nicolau). The saline marshes found on Sal gave the island its name.

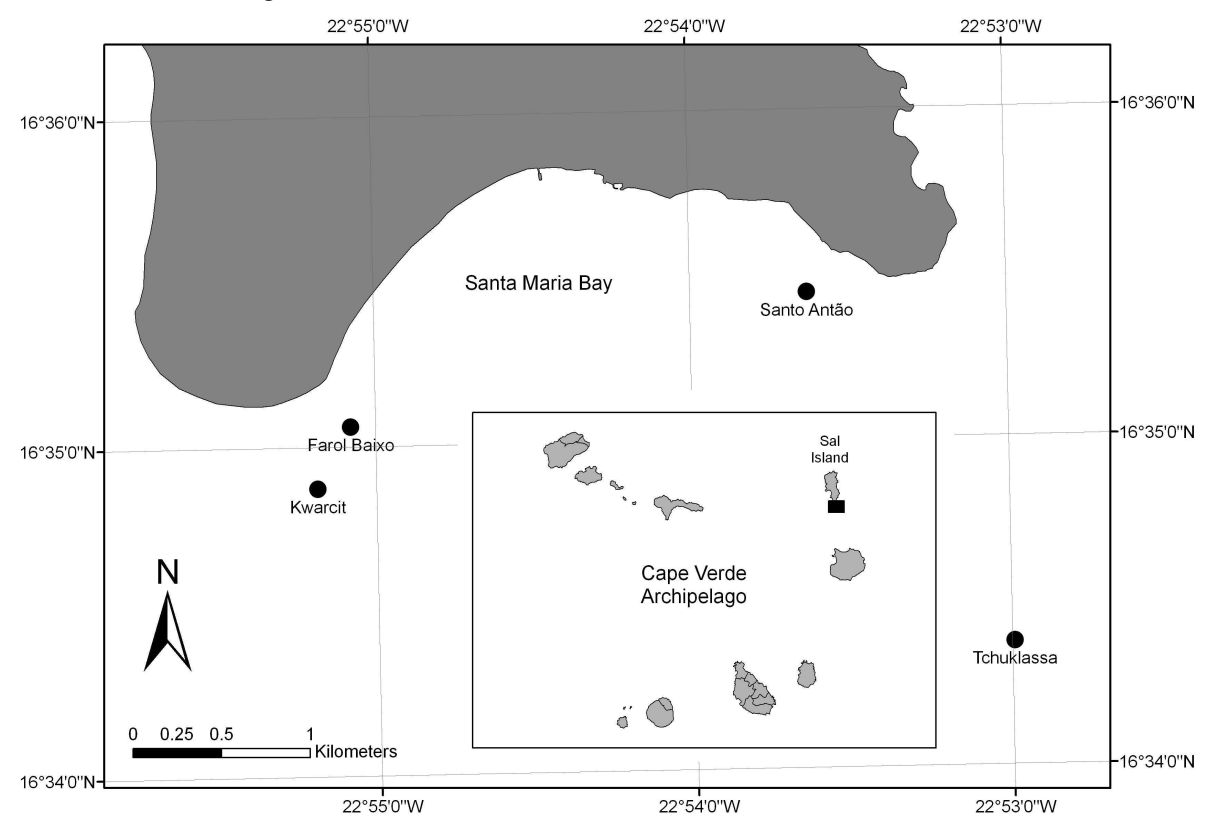

Until the 1980s the main economic activity was the production of salt for export. In recent decades tourism has supplanted the production of salt as the main activity (PINTO; ALMEIDA, 2005). During this period the population has increased greatly, due basically to the development of modern tourist resorts, based mainly on the town of Santa Maria on the southern tip of the island which has become the main tourist centre of the archipelago. Also on the bay on the southern coast there are long white beaches, of great interest to tourists, formed of the sand carried thither from the Sahara desert by the wind. Other places of aquatic tourist interest include the foaming lagoon of Buracona (IRWIN; WILSON, 2009).

According to Morri et al. (2000), knowledge on Cape Verde's marine biodiversity concerning both sessile and motile species is very limited. Even so, the synergies between different bodies on Sal Island have resulted in 'an environmental project with a social conscience' aiming to promote biodiversity. The project so far consists of the deployment of two ARs in Santa Maria bay (Kwarcit - a former soviet fishing vessel sunk in January 2006 and Sargo - an obsolete Cape Verdean navy patrol vessel sunk in April 2008). These ARs have diversified diving options between Tchuklassa (natural sanctuary of underwater fauna), the accidental shipwrecks (Santo Antão - carrier sunk in the 1960s) and other sites such as: natural reefs (Farol Fundo), caves (Três Grutas) and mixed (Farol Baixo - natural reef and a 1920s shipwreck) (see Fig. 1). 


\section{Data And Methodology}

\section{Data Collection and Stakeholders}

The present study to examine perceptions concerning the management of marine biodiversity on Sal Island was carried out basically by means of two instruments of data collection: a questionnaire using the AHP and secondary data. People were invited to answer a questionnaire taking into consideration some aspects of diving, and express their opinion accordingly. Respondents were informed about the creation of ARs on Cape Verde. They were asked to give their opinions, by means of a simple AHP methodology, about a future project aiming at marine biodiversity conservation on Sal Island and their preference regarding the allocation of money for each type of diving site, in the light of four different management options. Respondents were then asked to rank their preferred management measures. Respondents were subdivided into five stakeholder groups: 1) Biologists, 2) Diving operators (DOs), 3) Non-governmental organizations (NGOs), 4) Managers, and 5) Recreational divers (RDs). All those aware of local marine biodiversity issues were considered to be biologists. Diving operators were all those commercial enterprises located on Sal Island or elsewhere who had already organized diving activities on the island. All those stakeholders who had an interest in and were involved in biodiversity and management on Sal Island and represented local, national or international institutions were taken to be NGOs. All those who had any sort of involvement in environmental, tourism or fisheries management on Cape Verde were considered as managers. Finally, recreational divers were all those people that had been diving on Sal Island with independent tourist activities. Stakeholders' influence on a project's outcome may vary, as, on the other hand, may the impact of the project on each stakeholder group. However, for the purpose of the present study, each individual independent stakeholder group was considered to have the same weight in the decisionmaking process. Secondary data included information on the general development of tourism on Cape Verde and more specifically that focused on AR deployment projects. The internet sites of those diving operators working on Sal Island were also consulted.

The Analytic Hierarchy Process (AHP) Methodology

The AHP technique was developed by Thomas Saaty in the mid-1970s (SAATY; ROGERS,
1976) and has been used in a wide range of disciplines (SAATY; VARGAS, 2001). The potential of AHP is enormous and it is possible to use it in multicriteria decision-making, planning, conflict resolution, forecasting and in nearly all areas of knowledge (SAATY; ALEXANDER, 1981; TRIANTAPHYLLOU; MANN, 1995; ANANDA; HERATH, 2003; DE STEIGUER et al., 2003). In the social sciences the AHP can be used to quantify and derive measurements for intangibles. It can also be used to link hard measurements to human values, by interpreting what the measurements mean. The technique has been applied to a range of problems involving natural resource management (HERATH; PRATO, 2006), in a few instances to fisheries and aquaculture (LEUNG et al., 1998; MARDLE; PASCOE, 2003a,b; WHITMARSH; WATTAGE, 2006) and in reef diving choices (RAMOS et al., 2006). One study of site selection for artificial reefs (TSENG et al., 2001) has been made using the AHP. The AHP is essentially, basically a mathematical approach to decision making using pairwise comparisons. The technique considers both qualitative and quantitative aspects of related decisions. It reduces complex decisions to synthesized results thus making the decision-making process easier. The process consists of modeling a problem by using a hierarchical structure. In its essence, the AHP consists of a sequence of distinct steps (SAATY, 1990): (1) the definition of the problem, (2) the definition and selection of the elements for evaluation, (3) the selection of a set of alternative outputs, (4) the definition of a set of relevant criteria by which the alternatives are judged, (5) the construction of the hierarchical structure, (6) the gathering of information and choice of priorities, and finally (7) the preparation of recommendations for action. Usually the AHP model is represented by a schematic tree. Level zero is for the goal sought by the decision, level one establishes the criteria, and the lowest level of the tree is represented by the alternatives to the decision or other options (Fig. 2).

After organizing all the criteria and alternatives, the selection process begins. To make the pairwise comparisons, a 9-point scale was used by the convention of which the value of one was chosen to indicate that two items were of equal importance, while nine indicates that one item was absolutely more important than the other (Table 1).

Then a number of pairwise comparisons were made in order to establish factor weights and the following assessment. Paired comparisons were made between $n$ criteria and alternatives. In our case six comparisons were made for each level of the tree, as both the criteria and the alternatives were four (Table 2). In the end, the alternative with the highest total weight score was selected as the best one. 


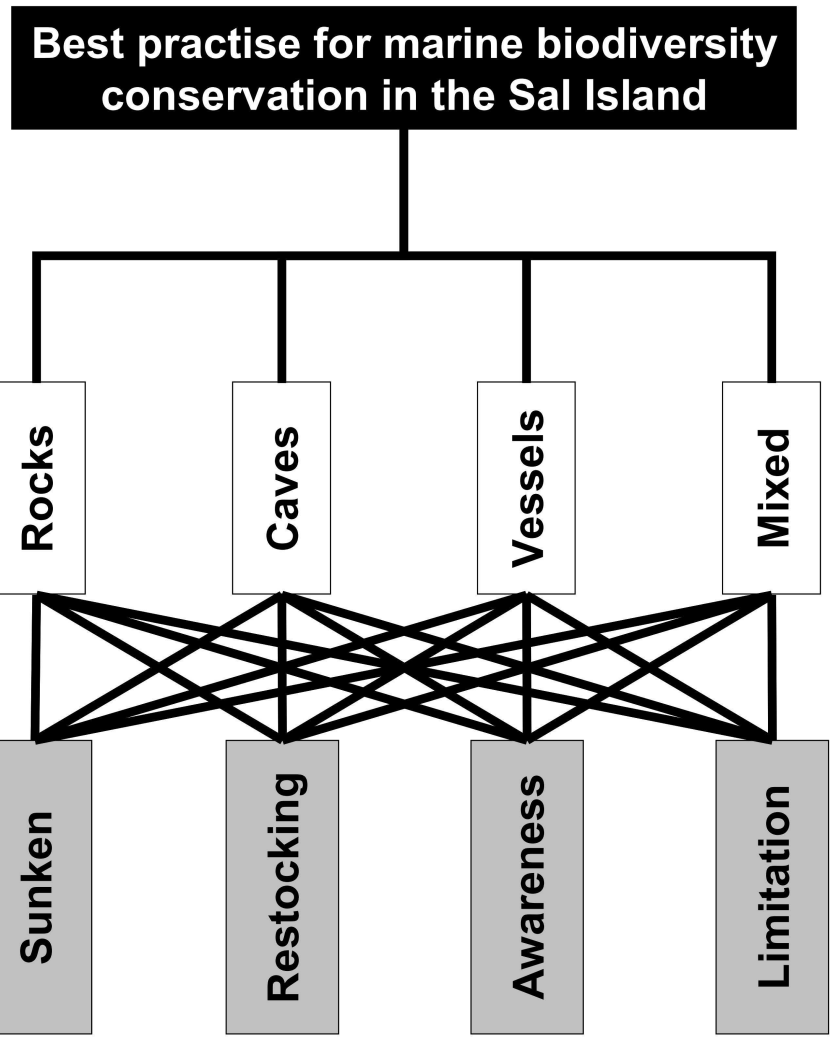

Fig. 2. The AHP tree model (goal, diving spot types and management alternatives).

Table 1. The AHP scale represents an intensity of importance.

\begin{tabular}{cll}
\hline \hline Score & \multicolumn{1}{c}{ Pairwise comparison } & Explanation \\
\hline 9 & Significantly more important & One item is favoured in the highest possible way \\
7 & Much more important & Dominance of one item in relation to another \\
5 & More important & One item is strongly favoured to another \\
3 & Moderately more important & One item is slightly favoured in relation to another \\
1 & Equally important & Two items contribute equally to the goal \\
$2,4,6,8$ & Intermediate values & Used to compromise between two comparisons \\
\end{tabular}

Table 2. Criteria, alternatives and their number of paired comparisons.

\begin{tabular}{ccc}
\hline \hline Level & Description & Number of paired comparisons \\
\hline Criteria & Rocks, Caves, Vessels and Mixed & 6 \\
Alternatives & Sunken, Restocking, Awareness and \\
Limitation & 6 \\
\hline
\end{tabular}


The aggregation of individual preferences was made by assuming that the group wants to act together though as separate individuals. The method used is called 'aggregating individual priorities' (AIP). By this method the aggregation of each individual's resulting priority weights is computed using the geometric mean and the Pareto principle is not violated. Forman and Peniwati (1998) state that "The Pareto (unanimity, agreement) principle essentially says that given two alternatives $A$ and $B$, if each member of a group of individuals prefers $A$ to $B$, then the group must prefer $A$ to $B$ ". A consistency ratio of $20 \%$ or less was used to consider the answers as reliable. If the consistency ratio was below $10 \%$, the answers were considered consistent. This also meant it was unnecessary to make much adjustment to the actual values of the eigenvector entries.

\section{AHP Evaluation: Diving Spot Types (Criteria)}

Incentives were given for the deployment of ARs on Sal Island. After preliminary studies carried out by specialists, the best locations were selected and the task of sinking the vessels was carried out. Prior to the survey some basic information related to the diving activities on Sal Island was provided. Having in mind the preservation of marine biodiversity in the Santa Maria Bay, the respondent should consider the most important diving spot types (criteria) on the island, according to the following distinctions: (1) Rocks were natural reefs characterized by being essentially rocky intrusions. (2) Caves were natural reefs that correspond to narrower or wider cavities with one or more openings. (3) Vessels were artificial structures accidentally or deliberately sunk. (4) Mixed were places that present both natural and artificial reefs within the same area. In terms of use, it was intended to minimize the first and second, to maximize the third and to maintain the last.

\section{AHP Evaluation: Management Measures (Alternatives or Options)}

The following management measures (alternatives) were also considered: (1) Sunken, the sinking of artificial structures (e.g. vessel-reefs) to widen the spectrum of diving sites and mitigate the damage caused to fragile habitats; (2) Restocking of living organisms including corals in order to maintain biodiversity and sustainability of diving activities; (3) Awareness on the part of the local community of the importance of the preservation of marine living organisms in the areas of diving interest; (4) Limitation of activities considered to threaten diving sustainability and marine biodiversity.

\section{AHP Sensitivity Analysis}

Different values were attributed for each of the variables analyzed, according to the respondent's judgment. However, it was important to know where each of the criteria and management options that had been evaluated by respondents was positioned. Thus a sensitivity analysis was carried out in order to ascertain the range of variation of each variable. Variable changes (i.e. diving spot type and management alternatives) show the range of preferences chosen by respondents. The objective of a sensitivity analysis is to identify the critical variables of the AHP model and show how the variability of each of the inputs will contribute to the best decision.

\section{Results}

Stakeholder Characteristics

The collection of data by means of the questionnaire survey took place between June 2009 and February 2010. Respondents were mostly required to answer a questionnaire delivered in situ. A total of 59 questionnaires were collected (Table 3). Each individual was considered as belonging exclusively to one stakeholder group.

Table 3. Survey response rate by stakeholder group.

\begin{tabular}{lccc}
\hline \hline Stakeholder & $\begin{array}{c}\text { Participants } \\
\text { group }\end{array}$ & $\begin{array}{c}\text { Usable } \\
\text { responses }\end{array}$ & $\begin{array}{c}\text { Usable } \\
\text { response } \\
\text { rate }(\%)\end{array}$ \\
\hline Biologists & 7 & 6 & \\
DOs & 4 & 3 & 86 \\
NGOs & 4 & 3 & 75 \\
Managers & 6 & 4 & 67 \\
RDs & 38 & 26 & 68 \\
Total & 59 & 42 & 71 \\
individuals & & & \\
\hline
\end{tabular}

The biologists questioned were responsible for studying local marine biodiversity and were usually engaged in projects in that field. Four out of the six DOs in Santa Maria Bay responded to the questionnaire. There were few NGOs on the island and they mostly represented international schemes (e.g., SOS Tartarugas). Managers were people who have some knowledge and expertise in terms of local fisheries and environmental management. Finally, RDs were usually non-residents who went to Sal island for tourism and/or diving purposes, due to the attractiveness of this tropical resort. Apart from DOs and managers, around two-thirds of the respondents 
were male, mostly non-residents (the majority being EU citizens). In terms of age, almost half the respondents were between 26 and 40 years old. Their level of education was usually high (4/5ths of the respondents had the equivalent of a university degree). The tourists' stay on the island usually varied from a few days to two weeks and for most of them it was their first visit to Sal Island. The majority of them dive just a few times a year, had less than fifty recorded dives, and only a few of them often travel abroad to dive.

Eliciting Respondents'

Priorities and Sensitivity Analysis Using the AHP

The results of the sensitivity analysis were represented by a boxplot and whiskers diagram (Fig. 3). The y-axis of the diagram showed the range of variation each management option has concerning the different criteria on the result, where the most sensitive variable is the largest box, which means that it had the maximum impact on the result. The horizontal line in each boxplot (i.e. the median) showed the base case answer for each of the variables (i.e. management options).
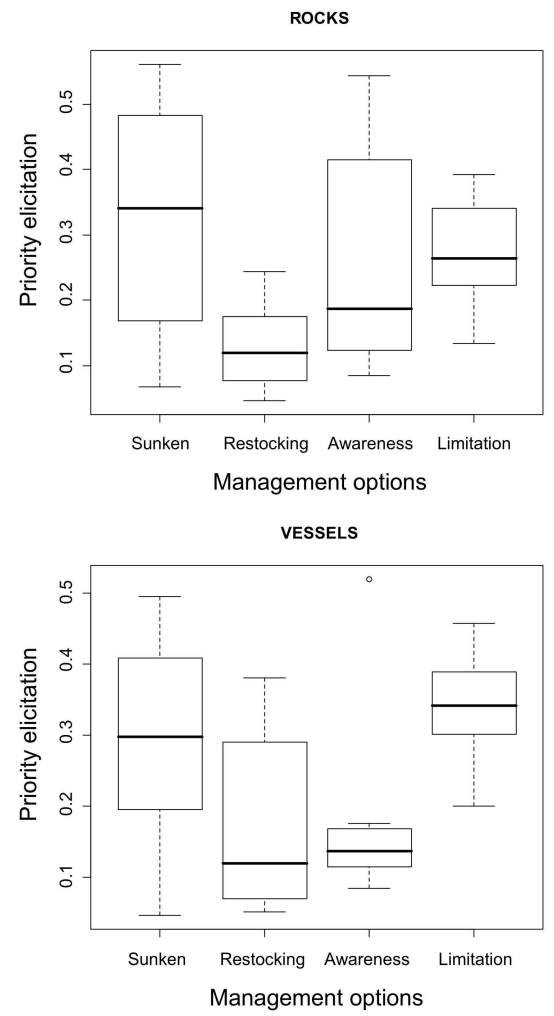

In rocky areas the most preferred management alternative was the deployment of obsolete structures (e.g. derelict vessels). It was also the most sensitive one (the eigenvalue varied between 0.170 and 0.480 ). In rock intrusion areas restocking was viewed as an option that did not make much sense. In diving spots based on caves the most sensitive management option - i.e. restocking - did not attain a consensus among the stakeholders, revealing many doubts or a lack of information such as would facilitate a decision (the eigenvalue varied between 0.120 and 0.450 ). On the other hand, the limitation of activities was the alternative that achieved the greatest consensus, it being considered very important to limit destructive practices in cave areas (its eigenvalue varies between 0.300 and 0.380 ). As in the case of caves, it was perceived by respondents that in areas where there were sunken vessels, intensive fishing activities should be minimized. Sinking more vessels as reefs had high preference, but this variable was somewhat sensitive $(0.200$ to 0.410$)$. Restocking did not achieve a high preference, but is highly sensitive (i.e. not consensual). Mixed areas showed high sensitivity for sunken structures (0.130 to 0.440$)$.
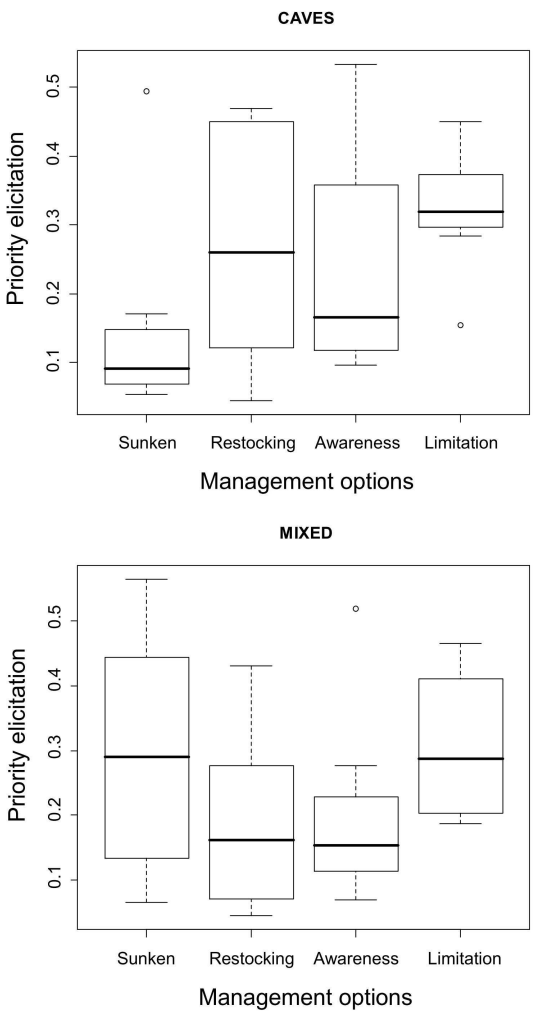

Fig. 3. Sensitivity analysis for diving spot types and management alternatives. 
AHP Evaluation and Decision to Make

So far we have used AHP to evaluate the options with regard to each of the criteria. What the decision makers (DMs) also need to do is to establish the relative importance of the management measures proposed (alternatives). Through the AHP procedure followed, the paired comparisons in respect of the four management alternatives (Sunken, Restocking, Awareness and Limitation), generated the priority weighting. The results of the sensitivity analysis were represented by a boxplot and whiskers diagram as shown in Fig. 4. The y-axis of the diagram shows the range of variation each stakeholder group presented concerning the variables in the result. The horizontal line in each boxplot (i.e. the median) shows the base case answer for each stakeholder. Sinking an obsolete structure is a management alternative that is not consensual, i.e., its choice is somehow dependent on the stakeholder group. It is the option preferred only by diving operators, half of whom prefer this option (the eigenvalue is over 0.500), but managers also strongly support the idea (they rank this option as their second preferred choice, after limitation of activities considered dangerous to diving sustainability and to local marine biodiversity). This management option is probably one of the most sensitive ones as there is a wide variety of opinion among stakeholders. Restocking, despite being the option that gathered fewest supporters (usually the eigenvalue lies between
0.050 and 0.200 ), was the most consensual. Only managers saw this option as having some potential, but it was considered sensitive. On the other hand, NGO representatives see no reason for restocking. Among the four management options assessed, restocking was also seen as the least sensitive. Awareness was a management alternative that did not achieve much of a consensus, i.e., its choice was highly dependent on the stakeholder group concerned. The eigenvalue lay over 0.600 in the case of NGOs and under 0.100 for managers. It was a sensitive variable among both biologists and NGOs (they show a large range of variation). NGOs see this option as by far the most important one concerning the best practice for marine biodiversity conservation on the island. None of the other groups considered this option as sensitive. Limitation is a management alternative that was in some measure consensual, i.e., its choice was not dependent on the stakeholder group. All stakeholder groups considered this variable as usually one of the most deserving of consideration. As well as the sinking of obsolete structures, this management option presented a wide range of variation among stakeholders, thus denoting great sensitivity. Recreational divers showed a high preference for the limitation management option (they present an eigenvalue of between, approximately, 0.200 and $0.600)$.
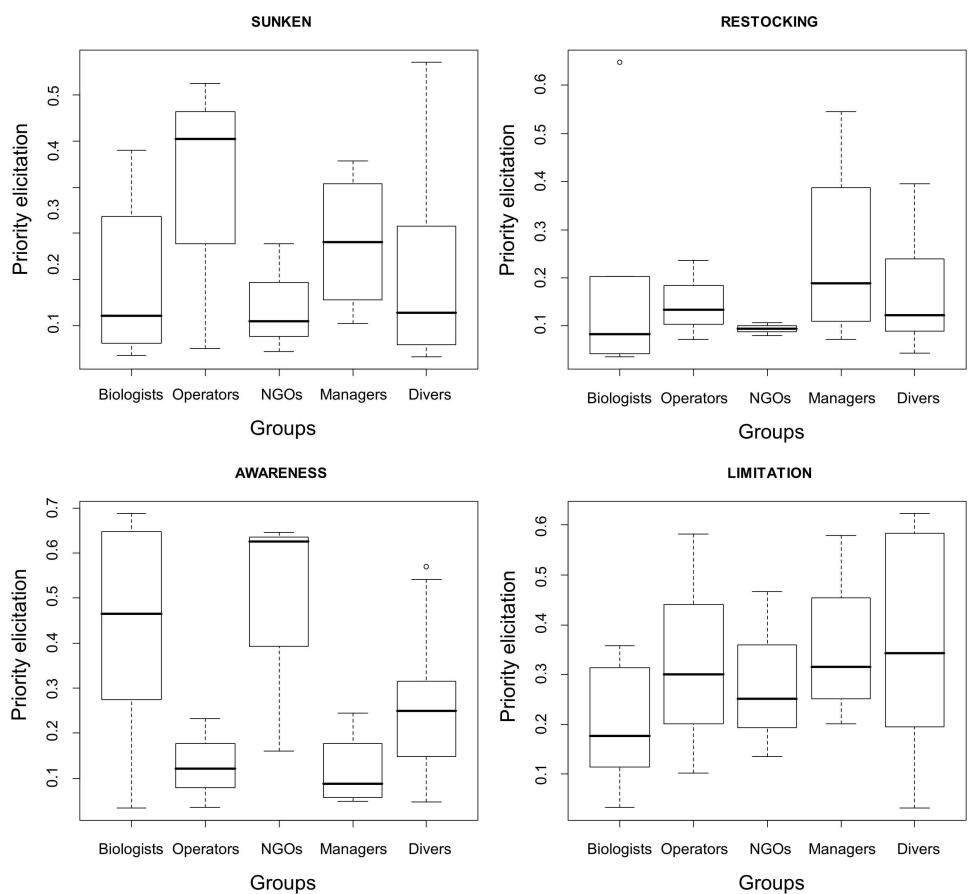

Fig. 4. Sensitivity analysis for the best management decision according to stakeholder group. 


\section{Discussion}

With the aid of the AHP, people were able to express their preferences regarding management options aiming at biodiversity conservation, according to the different diving spot types. In a first phase, when the overall individual choice was considered, the results of the present study showed that the most sensitive diving spot type was restocking in cave areas. This result denoted some ambiguity because it might be interpreted either as being regarded as very important to take into account in a near future restocking of some species in somewhat sheltered areas (i.e. caves), or as an option that should not be taken very seriously. The second most sensitive variables were reefing structures in rocky and in mixed diving spots. The least sensitive variable was awareness of vessel diving spots. Notwithstanding the above considerations, these results enabled us to understand the dynamics of the diving spot type variables and consequently gave some clues as to how to decrease the overall risk of the project.

The main focus should, however, be on the management options. Overall, of the management alternatives presented to represent the best practice for marine biodiversity conservation on Sal Island, the results presented in this paper suggest that, although there is no clearly defined management alternative consensual among all stakeholders, there was a higher priority call for limitation. This attitude expressed by the questionnaire survey respondents may reflect some perception amongst stakeholders that the limitation of potentially damaging activities should safeguard diving sustainability and mitigate the alleged risk of biodiversity loss at diving spots. The second preferred choice was not so easily perceived because it was dependent on the stakeholder group. A somewhat opposite view was expressed when comparing the sinking of obsolete structures with the awareness of the local community concerning the preservation of marine species. The least preferred choice was restocking. Probably stakeholders thought that there was no need to introduce species produced under controlled conditions because they perceived that there was no serious risk of biodiversity loss. It is interesting to note that the DOs' priority goes to the sinking of more derelict structures as reefs. This attitude may presume operators' interest in diversifying diving spots. Their interest in participating in and promoting projects related to marine biodiversity through using sunken vessels as reefs with a view to promoting underwater tourism is understandable. This result supports the idea that the demand for 'non-natural' habitats (where structures such as derelict vessels are included) is potentially high, as suggested by Leeworthy et al. (2006) and Ramos et al. (2006). Another interesting, noteworthy finding was that both biologists and especially NGOs accorded high priority to awareness, which reflects their concern for biodiversity conservation and recognition of the importance of sustainable and adequate use and practice of marine resources.

On Sal Island the effort aiming to contribute to the reconstruction of nature through the deployment of ARs is seen as protecting marine biodiversity from damaging fishing practices and simultaneously as widening the range of diving options by diverting diving from natural to artificial reefs. This action is believed to be an important preliminary step towards adequate management of marine biodiversity on the island. By creating better diving conditions, not only through diversifying diving spots, but also by assuring higher sustainability of its practice, it is supposed that more tourists can be attracted to and become particularly involved in diving activities. These activities create jobs and contribute to the social acceptability of such projects, involving an increasing number of local people who would otherwise be redundant or unemployed. Thus it is possible, through a synergistic effort, democratically and effectively to point to the right choices for the allocation of funds for a given project.

In terms of recommendations for action, the decision regarding the 'best practice for marine biodiversity conservation on Sal Island' would be for the promotion of greater protection for the rocky type diving spots and to facilitate the process of sinking obsolete or man-made structures in order to diversify diving spots. These results support a preliminary approach whereby divers would be diverted from natural to artificial structures. Since there is some fishing activity that has a certain economic and social impact in Santa Maria Bay, it is important to consider and understand the use of ARs not only for diving purposes, but also for the enhancement of fishing resources, since this affects the performance of the fisheries as a whole (RAMOS et al., 2006). There is no clear preference regarding the definition of a management plan, probably due to the lack of available information concerning the different aspects of the project (e.g., the availability of continuing funding resources and the tangible, longer-term objectives to be sought). This aspect of the question means that further studies should be commissioned.

\section{ACKNOWLEDGEMENTS}

Our appreciation goes to all those anonymous people who collaborated by filling in the questionnaire, and those who collaborated closely in providing valuable information for this study. We are grateful to colleagues P. Lino and J. Cúrdia for their help in the questionnaire pre-testing. Thanks are also due to Nuno Marques da Silva and Rute Portugal for 
helping conducting the questionnaires in Cape Verde. This study was carried out under the Rebuilding Nature project (www.rebuildingnature.org) funded by Manta Diving Center (www.mantadivingcenter.cv) and sponsored by: Banco Comercial do Atlântico, Soltrópico, Laranja Mecânica and Manta Diving Adventures.

\section{REFERENCES}

ALVES, L. M. M.; COSTA, A. L.; CARVALHO, M. G Analysis of potential for market penetration of renewable energy technologies in peripheral islands. Renew. Energ., v. 19, p. 311-317, 2000.

ANANDA J.; HERATH, G. The use of Analytic Hierarchy Process to incorporate stakeholder preferences into regional forest planning. Forest Policy Econ., v. 5, n. 1, p. 13-26, 2003.

BOURDET, Y. Reforming the Cape Verdean Economy. The Economics of mudança. Afr. Spectr., v. 35, n. 2, p. 121 163, 2000.

BRITO, A.; FALCÓN, J. M.; HERRERA, R. Características zoogeográficas de la ictiofauna litoral de las Islas de Cabo Verde y comparación con los archipiélagos macaronésicos. Rev. Acad. Canar. Cienc., v.18, p. 93109, 2007.

CHRISTIE, I. T.; CROMPTON, D. Tourism in Africa. Washington, DC: The World Bank, 2001. Africa Region, Working paper Series No 12. Available from: <http://www.worldbank.org/afr/wps/wp12.htm>.

DE STEIGUER, J. E.; DUBERSTEIN, J.; LOPES, V. L. The analytic hierarchy process as a means for integrated watershed management, 2003. Available from: <http://www.tucson.ars.ag.gov/icrw/Proceedings/>

FORMAN, E.; PENIWATI, K. Aggregating individual judgments and priorities with the Analytic Hierarchy Process. Eur. J. Oper. Res., v. 108, p.165-169, 1998

GROVE, R. S.; SONU, C. J. Fishing reef planning in Japan. In: D'ITRI, F. M. (Ed.). Artificial reefs: marine and freshwater applications. Chelsea, Michigan: Lewis Publishers, 1985. p. 187-252.

HERATH, G.; PRATO, T. Using Multi-Criteria Decision Analysis in natural resource management. Aldershot, England: Ashgate Publishing, 2006. 235 p.

IRWIN, A.; WILSON, C. Cape Verde Islands, The Bradt Travel Guide. 4th ed. UK, 2009. $327 \mathrm{p}$.

LEEWORTHY, V. R.; MAHER, T.; STONE, E. Can artificial reefs alter user pressure on adjacent natural reefs? Bull. Mar. Sci., v. 78, n. 1, p. 29-37, 2006

LEUNG, P., MURAOKA, J.; NAKAMOTO, S. T.; POOLEY, S. Evaluating fisheries management options in Hawaii using analytic hierarchy process. Fish. Res., v. 36, n. 2-3, p. 171-183, 1998.

LOPER, C. E.; BALGOS, M. C.; BROWN, J.; CICIN-SAIN, B.; EDWARDS, P.; JARVIS, C. Small islands, large ocean states: A review of ocean and coastal management in small island developing states since the 1994. Barbados Programme of Action for the Sustainable Development of Small Island Developing States (SIDS). University of Delaware, 2005. 87 p.
MARDLE, S.; PASCOE, S. (Ed.). Multiple objectives in the management of $\mathbf{E U}$ fisheries: the methodology. Portsmouth, U.K.: University of Portsmouth, 2003a. 56 p. Centre for the Economics and Management of Aquatic Resources, (CEMARE), Report n. 63.

MARDLE, S.; PASCOE, S. (Ed.). EU Multiple objectives in the management of fisheries: preference elicitation. Portsmouth, U.K.: University of Portsmouth, 2003b. 188 p. Centre for the Economics and Management of Aquatic Resources (CEMARE), Report n. 64.

MCELROY, J. L.; MORRIS, L. African island development experiences: A cluster of models. Bank Valletta Rev., v. 26, p. 38-57, 2002.

MENEZES, G. M.; TARICHE, O.; PINHO, M. R.; DUARTE, P. N.; FERNANDES, A.; ABOIM, M. A. Annotated list of fishes caught by the R/V ARQUIPÉLAGO off the Cape Verde archipelago. Arquipélago: Life and marine sciences, v. 21A, p. 5771, 2004.

MILON, J. W. Artificial marine habitat characteristics and participation behavior by sport anglers and divers. Bull. Mar. Sci., v. 44, n. 2, p. 853-862, 1989a.

MILON, J. W. Economic evaluation of artificial habitat for fisheries: progress and challenges. Bull. Mar. Sci., v. 44, n. 2, p. 831-843, 1989b.

MILON, J. W.; HOLLAND, S. M.; WHITMARSH, D. Social and economic evaluation methods. In: SEAMAN, W. (Ed.). Artificial reef evaluation: with application to natural marine habitats. Chapter 6. Boca Raton, Fla: CRC Press, 2000. p.165-194.

MORGAN O. A.; MASSEY D. M.; HUTH, W. L. Demand for large ship artificial reefs. Mar. Resour. Econ., v. 24, n. 1 , p. $43-59,2009$

MORRI, C.; CATTAENO-VIETTI, R.; SARTONI, G.; BIANCHI, C. N. Shallow epibenthic communities of Ilha do Sal (Cape Verde Archipelago, eastern Atlantic). Arquipélago: Life and marine sciences, v. Supplement 2 (Part A), p. 157-165, 2000.

MOTTET, M. G. Enhancement of the marine environment for fisheries and aquaculture in Japan. In: D'ITRI, F. M. (Ed.). Artificial reefs: marine and freshwater applications. Chelsea, Michigan: Lewis Publishers , 1985. p. 13-112.

PARKER, S.; KHARE, A. Understanding success factors for ensuring sustainability in ecotourism development in southern Africa. J. Ecotourism, v. 4, n. 1, p. 32-46, 2005

PINTO, J. R.; ALMEIDA, M. M. Epidemiology of asthma in schoolchildren in Portuguese speaking regions. Rev. Fr. Allergol., v. 45, n. 7, p. 547-549, 2005.

RAMOS, J.; SANTOS, M. N.; WHITMARSH, D.; MONTEIRO, C. C. The usefulness of the analytic hierarchy process for understanding reef diving choices: a case study. Bull. Mar. Sci., v. 78, n. 1, p. 213-219, 2006.

SAATY, T. How to make a decision: the analytic hierarchy process. Eur. J. Oper. Res., v. 48, n. 1, p. 9-26, 1990.

SAATY, T. L.; ALEXANDER J. M. Thinking with models: mathematical models in the physical, biological and social sciences. New York: Pergamon Press, 1981. 181 p. 
SAATY, T.; ROGERS, P. C. Higher education in the United States (1985): scenario construction using a hierarchical framework with eigenvector weighting. Socio Econ. Plan. Sci., v. 10, p. 251-263, 1976.

SAATY, T. L.; VARGAS L. G. Models, methods, concepts \& applications of the analytic hierarchy process. Boston, MA: Kluwer Academic Publishers, 2001. 333 p.

SEAMAN JR, W. ; JENSEN, A. C. Purposes and practices of artificial reef evaluation. Chapter 1. In: SEAMAN, W. (Ed.). Artificial reef evaluation: with application to natural marine habitats. Boca Raton, Fla: CRC Press, 2000. p. 1-19.

SEMENIUK, C. A. D.; HAIDER, W.; BEARDMORE, B.; ROTHLEY, K. D. A multi-attribute trade-off approach for advancing the management of marine wildlife tourism: a quantitative assessment of heterogeneous visitor preferences, Aquat. Conserv., v. 19, p. 194-208, 2009.

TAPPER, R. Wildlife watching and tourism: a study on the benefits and risks of a fast growing tourism activity and its impacts on species. Report prepared for United Nations Environment Program (UNEP) and the Secretariat of the Convention on the Conservation of Migratory Species of Wild Animals (CMS), 2006. 65 p.
TRIANTAPHYLLOU, E.; MANN, S. H. Using the analytic hierarchy process for decision making in engineering applications: some challenges. Int. J. Ind. Eng-Appl. P., v. 2 , n. 1 , p. $35-44,1995$.

TSENG, C. T.; CHEN, S. C.; HUANG, C. S.; LIU C. C. GIS-assisted site selection for artificial reefs. Fish. Sci., v. 67, p. 1015-1022, 2001.

WHITMARSH, D.; WATTAGE, P. Public attitudes towards the environmental impact of salmon aquaculture in Scotland. Eur. Environ., v. 16, n. 2, p. 108-121, 2006.

WILKINSON, P. F. Strategies for tourism in island microstates. Ann. Tourism Res., v. 16, n. 2, p. 153-177, 1989.

(Manuscript received 23 May 2010; revised 10 April 2011; accepted 11 April 2011) 